\title{
Redefining the dynamics of intergenerational family solidarity in Spain ${ }^{1}$
}

\author{
Jordi Caïs, Laia Folguera \\ (University of Barcelona)
}

\begin{abstract}
$\underline{\text { Abstract }}$
This article analyses the dynamics of family solidarity in Spain. The existing literature so far has defined the Spanish caring model as familistic due to the primacy of the family in the protection of dependants. However, this article shows that recent data on Spaniards' preferences concerning the care of their family dependents might question the sustainability of the bases of such model. This is consistent with the results of the OASIS Project (Lownstein and Daatlan 2006), according to which societal changes may be leading to family care becoming less duty-driven and more dependent on personal affection and attachment. $^{2}$ The Spanish welfare state is labelled as familistic because family makes up for the lack of public benefits dampening adverse economic cycles and the problems of its more fragile members: children, young people and, especially, the elderly. Family solidarity is considered beneficial because it contains public spending and generates positive effects of solidarity and security in the population. Moreover, the expectations of the dependent elderly are focused on family, not on social services that always have been scarce in Spain and they are worsening with the economic crisis. But the Spanish welfare state based on familist values appears to be increasingly ineffective and more difficult to sustain. This article explains how changes in family structure and dynamics, along with the high rates of female labour force that Spain has recently achieved, affect family caregiving preferences and strategies.
\end{abstract}

Keywords: Spanish welfare state, dependency care, familist values, intergenerational solidarity

\section{Introduction}

The Spanish welfare state is labelled as familistic due to the primacy of the family in the protection of dependants. In Spain, mechanisms of family solidarity ensure minimum levels of well-being where public policies do not provide coverage. Nowadays, in spite of governments' efforts to promote familist values in some centre and North-European countries, the Spanish welfare state based on familism may be in crisis. The social and economic context has changed and, while in Spain intergenerational solidarity within the family still enjoys social prestige, people can hardly spend so much time caring for their relatives as they did before. In the "Parsonian" family model that characterizes familist societies, women are in charge of caring for dependent relatives. However, nowadays this

\footnotetext{
${ }^{1}$ We thank Marga Mari-Klose for her help and comments on the multivariate statistical analysis.

2 The five-country (Norway, England, Germany, Spain and Israel) OASIS study collected data from representative, age-stratified, urban-community samples of about 1,200 respondents in each country.
} 
model generates moral doubts. The "second demographic transition" (Van de Kaa 1987) has arrived later in Spain than in northern and central Europe, albeit abruptly. Spanish population is ageing very quickly, with a significant impact on society. On the one hand, from 1990 to 2010 life expectancy in Spain has increased five years, reaching 82, and the percentage of population over 64 years old has increased by more than $3 \%$ to over $16 \%$ of the total Spanish population (INE 2012). On the other hand, Spanish women are no longer socialized to exercise the role of housewife. They have acquired the same level of education than Spanish men and they are joining the labour market in proportions similar to those of countries in central Europe. Moreover, at present, most Spanish families with children need two wages to get rid of the risk of falling into poverty. The welfare state in Spain has not developed social services to substitute for the role women have traditionally played through informal caring. As an example Spain has one of the lowest rates of kindergarden services per capita as well as the one of the scarcest services in Europe for the caring of elderly dependence (Moreno and Bruquetas 2011), a situation that is worsening as a result of the current economic crisis. Spanish families react to the limited social policies of the Spanish welfare state by having fewer children, but it is not possible to "have fewer grandparents". For many families, combining professional activities with care for elderly dependents has become a problem that is difficult to solve.

This article analyses changes in the dynamics of family solidarity in Spain. We focus on how changes in family structure and dynamics, and the high rates of female labour force that Spain has recently achieved, affect family caregiving strategies. We also study whether people still care for reasons related to reciprocity, affection or duty, and to what extent the scarcity of public services and the high cost of private services are important as explanatory variables of the Spanish high rates of family caregivers. ${ }^{3}$ Most of the studies on intergenerational family solidarity analyse whether a generous welfare state could undermine family solidarity. However, in the case of Spain, the question should be the opposite: can the Spanish model of elder care based on family solidarity remain unchanged taking into account the changes that have occurred in the family and the labour market? How sustainable is the Spanish model of elder care based on the generational contract between parents and adult children in the new socioeconomic context, where crisis has led to a substantial decrease in the public resources spent on social services for dependents ${ }^{4}$ And finally: Has intergenerational family solidarity weakened? Have new social realities, such as gender equality and increased female participation in paid work, influenced the ways in which filial norms are translated into emotional and instrumental support and help? Is family care becoming less duty-driven and more dependent on personal affection and attachment? All these questions are particularly relevant when we take into account recent data on Spaniards' preferences concerning dependence care, which might challenge the bases of intergenerational family solidarity, and which we analyse later on in this article.

\footnotetext{
${ }^{3}$ Coverage rates of social services for dependent elderly (home care services and nursing, among others) do not reach even $5 \%$ of people over 65 (Tobío et al. 2010).

${ }^{4}$ In the recent electoral campaign that led to the victory of the new PP government, this political party openly acknowledged that some social programs for the dependents would have to be suspended until the economic situation improves.
} 


\section{Theoretical frame}

It is widely accepted that interpersonal relationships among family members remain within the private sphere and that the process of receiving and providing care within families is mainly based on affection and reciprocity. Gouldner (1960) states that there is an implicit contract between generations within the family. Parents are required to invest a high proportion of their resources in the care of children. Therefore, when these parents get older, they expect that the provision of care will be reversed so that children should invest resources in caring for parents. Marshall (1987) states that the nature of caring relationship is based on a delicate balance between reciprocity, affection and duty.

The welfare system based on the caring role of family networks enjoys considerable legitimacy among academics and politicians for being "natural", "altruistic" and because it develops quite effectively the functions entrusted to it (Marí- Klose and Marí-Klose 2006). They also argue that the model is very strong since it enjoys a wide social acceptance in southern Europe, where intergenerational family solidarity is understood as an unwavering value. The Spanish welfare regime is a clear example of the Mediterranean familistic welfare state model. Spanish public policies of social protection primarily ensure the safety of the family as an economic unit. But, in return, they expect the family to take care of most needs of its members. Family makes up for the lack of public benefits dampening adverse economic cycles and the problems of its more fragile members: children, young people and, especially, the elderly. Family solidarity is considered beneficial in every way: on the one hand, it contains public spending and, on the other hand, it generates positive effects of solidarity and security in the population. Therefore, the state is reluctant to provide social services in order not to discourage family informal care and breaking the intergenerational family contract.

In the past three decades, the family in Spain has been affected by a profound change that affects their ability to care for their dependent members, especially the elderly disabled. The inherited social rules that have defined the structure and roles of family members in the past have become obsolete. The figure for women exclusively devoted to housework and caring for children, parents and husband is dying (Marí-Klose and MaríKlose 2006). Taking care of dependent people mainly by women is increasingly seen as unfair (Brullet y Torrabadella, 2004). Often, Spanish families with children need two salaries to live without economic woes, and women have joined the labour market (Iglesias de Usel, et. al. 2009). For many families, combining professional activities with care for elderly dependent has become a problem, and in many cases the person taking care has been forced to abandon their work. In addition, the emergence of new family models such as single parents and blended families (Flaqué et. al. 2006) generate new challenges for family solidarity.

The present article addresses two hypotheses. Our first hypothesis is that changes in family structure and dynamics, together with increasing participation of women in the labour market in Spain, are influencing people's preferences about how to care for dependants: care is becoming less duty-driven and more dependent on personal affection and attachment. Our second hypothesis is that dependants care is less understood as a moral duty that has to be assumed personally, and more as a responsibility that may be 
addressed through different means. We want to test whether a bad economic situation or a poor family network lead to a higher probability to prefer social care instead of family care. This hypothesis is in line with the theoretical frame of "packaging and patchworking" describes (Knijn 2004). This theory states that families, especially women, combine all kinds of resources to carry out care for dependants. They do so regardless of the availability of social services offered by the state or even changes in that offer. This is a theoretical model that Knijn adapted from the concept of "income packaging" introduced by Rainwater et al. (1986). They studied the combination of resources used by poor American families to overcome difficult periods of unemployment and illness. We want to test whether this hypothesis offers an explanation on how Spanish family caregivers would prefer to combine services trying to make care and work compatible.

\section{The approach to the problem}

In this section we describe firstly the phenomenon of incorporation of Spanish women into the labour market in the last 15 years, which is higher to that of any other European country. Secondly, we emphasize that, despite these changes, the disabled people are still cared mostly by members of their own family. We highlight that the lack of public policies addressed to dependants in Spain is a possible explanation for the high number of Spaniards who have to take care by themselves for their dependent relatives. Finally, we show data about the consequences that taking care of a dependent relative has to the caregivers for their position in the labour market. Often, the difficulties of combining working life with taking care of dependent relatives force the caregiver to abandon his/her paid work. These three main points may help understand why the data presented in the next section -about the preferences for who should care for dependent relatives-, might question the basis on which the Spanish familistic model is founded.

The increasing individualization of society has profoundly altered the structure and functioning of the family (Beck 1986). Individual rights have been prefixed to the family institution (Meil 2006). Individualization implies less social control over individual life projects in the family. The variety in choices of way of lives is now broader, especially for women, who move from a life model oriented to family service to another in which they assert their right to have also an own career. In Spain, the number of women who are dedicated exclusively to home and who are the foundation on which familism rests has been halved in the last two decades. In 1988, $42 \%$ of women were engaged only in household chores. In 2008 this figure had fallen to 23\%. At present, less than a quarter of Spanish women of working age are engaged in household chores. Furthermore, these women devoted exclusively to household chores are much older. In 1988 nearly $35 \%$ of housewives were older than 55 years old. Twenty years later, in 2008, this proportion had risen to almost 50\% (Tobío et al. 2010). Moreover, in the last two decades a large number of Spanish women have entered into the labour market and female employment rates have been growing rapidly. In twenty years, Spain has increased female participation rate in $25 \%$. It has gone from being the country with the lowest female participation rate in the $\mathrm{EU}$, to have a volume of female labour force comparable to that of France, Germany or the UK. Table 1 compares the female activity rates in different countries of the EU15 and 
shows that, in the last decade, female participation rate in Spain has grown 15 percentage points -much faster than in other countries. This rate has increased from 50\% in 1999 to $65 \%$ in 2009 and almost reaches the female activity rate of the EU15 average. ${ }^{5}$

Table 1

Female activity rate in countries of UE15, 1999-2009

\begin{tabular}{|c|c|c|c|c|}
\hline & \multicolumn{2}{|c|}{ Female activity rate } & \multicolumn{2}{|c|}{$\begin{array}{c}\text { Female part-time employment } \\
(\% \text { total employment })\end{array}$} \\
\hline & 2009 & $\begin{array}{c}\text { Increase } \\
1999-2009\end{array}$ & 2009 & $\begin{array}{c}\text { Increase } \\
1999-2009\end{array}$ \\
\hline Spain & $64.8 \%$ & $14.8 \%$ & $23.0 \%$ & $5.9 \%$ \\
\hline Greece & 56.5 & 6.2 & 10.4 & 0.4 \\
\hline Italy & 51.1 & 5.6 & 27.9 & 12.3 \\
\hline Portugal & 69.0 & 6.1 & 16.4 & -0.3 \\
\hline Germany & 71.4 & 8.4 & 45.3 & 7.9 \\
\hline Belgium & 60.9 & 4.6 & 41.5 & 4.6 \\
\hline France & 66.3 & 4.0 & 29.8 & -1.6 \\
\hline Denmark & 77.3 & 1.2 & 37.9 & 3.2 \\
\hline Finland & 73.5 & 2.4 & 19.0 & 2.1 \\
\hline Holland & 74.1 & 8.9 & 75.8 & 6.9 \\
\hline Sweden & 78.9 & 2.1 & 41.2 & 7.9 \\
\hline United Kingdom & 69.5 & 1.6 & 42.5 & -1.5 \\
\hline UE15 & 65.9 & 6.6 & 37.0 & 3.8 \\
\hline
\end{tabular}

Source: EUROSTAT, Employment in Europe, 2010 (Luxembourg, European Commission: 2010) .

Note: Female activity rates are calculated as the total amount of female labour force (employed and unemployed) as a share of total population in the corresponding age bracket.

Despite the changes in family and houshold structure and the incorporation of women in the labor market, older people with disabilities are still being cared primarily by family members - mostly women. A survey on disability, personal autonomy and dependency situations by National Institute of Statistics (INE) in 2008 shows that $55 \%$ of people who need care receive them from their families, mainly from children, and secondly from the spouses. Three out of four primary caregivers of dependent people in Spain are women. In fact, the profile of the usual caregiver in Spain is a woman (usually the daughter) between the ages of 45 and 64 of the same family, and residing in the same household as the person who is being taken care of. For many Spanish families to take care of their disabled members is the only option, as social assistance for families with disabled people is marginal in Spain, and often families cannot afford the high prices of private professional home-care or private residences for the elderly. The Spanish public network

\footnotetext{
5 The Spanish female activity rate today is close to that of countries like France or Germany with conservative welfare regimes. And if we consider that the percentage of women working part time in Spain $(23 \%)$ is much lower than that of women working part time in France (30\%) and Germany (45\%), we could think that the level of incorporation of Spanish women into the labor market is even higher than in those countries. The same thing happens in Britain with a model of liberal welfare state based primarily on the labor market. UK has a female activity rate of $70 \%$ which is five percentage points higher than Spain, but $42.5 \%$ of women working part time, while in Spain it's only $23 \%$. Only Scandinavian countries with a welfare state model which makes special emphasis on sharing family responsibilities, have employment rates above the Spanish.
} 
of services for dependence is fragmented and achieves low coverage rates in comparison with neighbouring countries. ${ }^{6}$

Sarasa (2007) makes a comprehensive contribution to understand factors that link social class and family solidarity. In Spain, on the one hand, poor health and risk of disability is higher among lower social classes, so the dependency ratio of the elderly is higher in low-income households. On the other hand, the use of care services is more frequent in households with higher disposable incomes and higher level of education. The level of disposable income is a good indicator to understand the use of private and public services: higher income implies higher capacity of access to private services and vice versa. Even though, Sarasa points out that the assumption that to have lower income implies more access to the scarce public social services is not clear, since there are other variables involved, such as educational level and cultural capital (the higher cultural capital the greater the ability to seize opportunities that public system offers).

The shortage of public policies for dependants in Spain may help understand the caring role of families in this country. Using data from OASIS project, Daatland and Lowenstein (2005) argue that intergenerational solidarity is substantial both in northern and southern welfare states, and seems to vary in character more than in strength. However, the difference in the volume of services and the access between public services offered by the Norwegian and the Spanish welfare state makes the experience to take care in Norway and in Spain hardly comparable. ${ }^{7}$ Southern European states consider caring a private matter that has to be internalized within the family and Scandinavian states have assumed the societal responsibility of caring for their dependent citizens (Sarasa and Mestres 2007). On the one hand, The National Background Report for Norway's EUROFAMCARE (2004) indicates that in 2000 the Norwegian family caregivers spent on average just over two hours caring for their relatives. Norwegians prefer public services to the care of the family because they respond better to the needs of older people and their families. Older Norwegians expect emotional support rather than care from their families. On the other hand, the White Paper on Dependency in Spain (2005) indicates that in 2004 Spanish family caregivers were involved in caring for their dependent relatives an average of ten hours a day. In Spain the family is the source of major support and care for the elderly; public services are scarce and families are not familiarized with them. ${ }^{8}$ The expectations of the dependent elderly are focused on family, not on social services. Normally, children are those who have to take on the responsibility that taking care of them entails. Family support networks are very important to understand the use of public and private services that attend dependents in Spain. Single, divorced and separated people

\footnotetext{
${ }^{6}$ The evidence of this weakness was acknowledged by the out coming socialist government, and used as the main argument for the approval of the 2006 dependency low. Despite the social and political expectations put on this low, its implementation was initially jeopardized by the scarce resources allocated to it, and afterwards by the economic crisis.

${ }^{7}$ Bazo y Ancizu (2004) use in-depth interviews conducted in Norway, Germany, United Kingdom, Israel and Spain during the OASIS Project to explain the interactions service-person-family that occur in countries with different welfare state models and policies to support families. Their study finds that the possibility of access to social services determines different patterns of interaction and caring relationships between dependent parents and their children.

${ }^{8}$ In villages, familiarity with social services is even lower than in cities. The scarcity of formal resources, both public and private, in municipalities under 50,000 inhabitants forces families to take care of their dependents even more than what families of large and medium cities have to assume (Sarasa 2007).
} 
are those who most often have to resort to the market, volunteers or public social services (Sarasa 2007).

Being the main caregiver of a disabled person in Spain often is a full time job, incompatible with participation in the labour market. This affects the level of family income and, in some cases, the family risks to fall into poverty levels. One out of five caregivers state that he/she has economic problems (INE 2008). Sarasa and Billingsley (2008) argue that there exists a trade-off between caregiving to aged parents and paid employment, pulling children out of the labour market when parents' needs are great and no alternative resources are available. The demanding characteristics of taking care of someone in Spain, in many cases, makes caring incompatible with the possibility to work in the labour market $-25 \%$ of caregivers said that they found themselves in this situation(INE 2008). In many cases the need to care for an elderly dependent forces the family to give up an additional salary. According to Sarasa (2008), Spain shares with other countries with Conservative and Mediterranean welfare regimes a similar bias in favour of cash transfers towards the elderly and handicapped. ${ }^{9}$ And a policy focused on cash transfers is not neutral at all; in comparison with service provision, cash transfers reduce the opportunities of conciliation between paid work and care giving demands.

The Spanish model of elder care based on family solidarity involves very high economic and social costs for Spanish families. Spaniards are becoming more aware of it because, according to the Barometer of the Sociological Research Centre, two out of three Spaniards would be willing to pay more taxes to finance support services for families (CIS 2004). It is may be the case that such costs and the difficulties facing today Spanish families when caring for their dependants have affected Spaniards' preferences about the type of help they should offer to their dependents.

\section{Spaniards' preferences concerning dependence care: Recent trends}

In this section we analyse recent data on Spaniards' preferences concerning dependence care, which might challenge the bases of intergenerational family solidarity. We have created a logistic regression model using data from the CIS Barometer September 2010 (Table 2). ${ }^{10}$ The dependent variable is a dummy variable constructed on the bases of a survey question where the respondent has to choose between social services and family care in the case of a dependent elder familiar. The reference category in the statistical model is: to agree that when a person cannot care for oneself it is better to rely on social services rather than on family. The independent variables include economic status and variables related to the structure, dynamics, and quality of family relationships, and

\footnotetext{
${ }^{9}$ Pensions and other transfers make up the bulk of expenditure, and, theoretically, beneficiaries can buy the services they need in the market but this possibility is realistically limited to a minority and thus reinforces inequalities (Sarasa and Mestres 2007).

${ }^{10}$ The data for this multivariate analysis are from CIS Study 2844: Barometer of September 2010. A representative sample of 2,473 Spanish people stratified by gender, age, autonomous regions and municipality size were interviewed in their homes about family values.
} 
confidence in the public social services. As statistical control variables the model includes age, sex, municipality size, educational level, religion and marital status.

We want to determine whether Spaniards' preferences concerning the care for their dependants increasingly resemble what the theoretical frame of "packaging and patchworking" describes. To this end, it will be useful to see whether the economic situation of the family affects its disposition to care their older relatives. It is also important to see whether the degree of confidence that families have in social services has any influence on their disposition to rely on them. We also want to find out whether people with weak family networks will tend to prefer a model where public social service provision is more present. Finally, we will see whether factors such as quality of relationships among family members affect the desire to provide care for elderly dependent relatives. 
Table 2

Logistic regression model

Dependent variable: to agree that when a person cannot care for oneself it is better to rely on social services rather than on family

\begin{tabular}{|c|c|c|c|c|c|c|}
\hline & BLOCK1 & BLOCK2 & BLOCK3 & BLOCK4 & BLOCK5 & BLOCK6 \\
\hline \multicolumn{7}{|l|}{ Sociodemographic variables } \\
\hline \multicolumn{7}{|l|}{ Age $^{1}$} \\
\hline 25 to 50 & 1 & 1 & 1 & 1 & 1 & 1 \\
\hline 51 to 65 & $1,474^{* *}$ & $1,548^{* *}$ & $1,556^{* *}$ & $1,550 * *$ & $1,472^{* *}$ & $1,408^{*}$ \\
\hline More than 65 & $1,491^{* *}$ & $1,507^{* *}$ & $1,540 * *$ & $1,523^{* *}$ & 1,357 & 1,296 \\
\hline \multicolumn{7}{|l|}{ Sex } \\
\hline Male & & 1 & 1 & 1 & 1 & 1 \\
\hline Female & & 1,029 & 1,027 & 1,024 & 1,043 & 1,081 \\
\hline \multicolumn{7}{|l|}{ Size of the Town } \\
\hline More than 1 million & & 1 & 1 & 1 & 1 & 1 \\
\hline From 100.001 to 100.000 & & $0,701^{\wedge}$ & 0,721 & 0,712 & 0,717 & 0,697 \\
\hline From 10.001 to 100.000 & & $0,642^{*}$ & $0,653^{*}$ & $0,647^{*}$ & $0,629 *$ & $0,632^{*}$ \\
\hline Since 10.000 & & 0,739 & 0,760 & 0,754 & 0,734 & 0,709 \\
\hline \multicolumn{7}{|l|}{ Educational Level } \\
\hline University & & 1 & 1 & 1 & 1 & 1 \\
\hline Secondary & & $1,352^{\wedge}$ & 1,226 & 1,232 & 1,139 & 1,190 \\
\hline Primary & & 1,104 & 1,047 & 1,048 & 1,018 & 1,060 \\
\hline \multicolumn{7}{|l|}{ Religiosity } \\
\hline No believer & & 1 & 1 & 1 & 1 & 1 \\
\hline Believer & & $0,678^{* *}$ & $0,675^{* *}$ & $0,672^{* *}$ & $0,659^{* *}$ & $0,679 * *$ \\
\hline \multicolumn{7}{|l|}{ Marital Status } \\
\hline No married & & 1 & 1 & 1 & 1 & 1 \\
\hline Married & & $0,758^{*}$ & $0,791^{\wedge}$ & $0,790^{\wedge}$ & 0,794 & 0,873 \\
\hline Economic situation ${ }^{2}$ & & & $1,144^{\wedge}$ & $1,149^{\wedge}$ & 1,094 & 1,064 \\
\hline $\begin{array}{l}\text { Degree of confidence on social } \\
\text { services }\end{array}$ & & & & 1,011 & 1,012 & 1,028 \\
\hline \multicolumn{7}{|c|}{ Variables of structure and internal family dynamics } \\
\hline \multicolumn{7}{|c|}{ Number of potential caregivers } \\
\hline More than 6 & & & & & 1 & 1 \\
\hline From 3 to 5 & & & & & 1,156 & 1,091 \\
\hline From 0 to 2 & & & & & $2,348^{* * *}$ & $2,029 * *$ \\
\hline Degree of family cohesion ${ }^{3}$ & & & & & & $1,131^{* *}$ \\
\hline \multicolumn{7}{|l|}{$\begin{array}{l}\text { Degree of satisfaction with the } \\
\text { family }\end{array}$} \\
\hline High & & & & & & 1 \\
\hline Medium & & & & & & $1,376^{*}$ \\
\hline Low & & & & & & $3,182^{* *}$ \\
\hline R2 Nagerkelke & $1,1 \%$ & $3,2 \%$ & $3,5 \%$ & $3,5 \%$ & $7 \%$ & $9 \%$ \\
\hline Number of cases & 1.494 & 1.494 & 1.494 & 1.494 & 1.494 & 1.494 \\
\hline
\end{tabular}

$\wedge$ Level of signification $10 \%$

* Level of signification $5 \%$

** Level of signification $1 \%$

*** Level of signification 1/000

Source: CIS N 2844 Study Barometer September 2010 (Center for Sociological Research)

Notes: 1 The Matrix, having selected only those over 25, consists of 2234 cases.

2 The scale ranges from very good to very bad economic situation.

3 We constructed an index variable from two variables: "visit or see their families, although there is no reason for it" and "celebrates important dates (birthdays, Christmas, etc.) with members of his/her family. The family index ranges from more to less family cohesion. 
The results of the logistic regression analysis shows, in the first block, that age is a significant variable in its three categories without controlling for the other variables in the model. At first sight it would seem that intergenerational solidarity is even reinforced. The odds ratio of considering that an elderly dependant should go to social services rather than to rely on one's family is higher in the middle generation (51 to 65 years old) and in the older generation (more than 65 years old) than in the younger (25 to 50). With this data it seems that young people are even more willing to offer aid than elderly people. However, once we introduce the variables of structure and family relationships in the model, age is no longer significant for the group of people over 65 years old, and it only remains so for the group of 51 to 65 . We conclude, therefore, that it is in the group that fits the higher frequency of caregiving where it is more common to find people who think that when a family dependant cannot care for oneself it is better to rely on social services rather than on family. This age group frequently has to confront the dilemma of having to juggle their work outside home and take care of the dependent family members.

In the second block of the logistic regression model we find the socio-demographic variables that are used for statistical control. The only ones that remain significant after introducing the variables of structure and family relationships are the size of the town where the respondent resides and religiosity. In small towns (10,000 to 100,000 inhabitants), the odds ratio of considering that it is better to rely on social services for the care of family dependants rather than on family care is about half in comparison to large cities with more than one million inhabitants. People's religiosity is also closely linked to family solidarity. The probability that a religious person expresses a preference for family caring of dependants instead of relying on social assistance doubles that among nonreligious people.

In the third block of the model we introduce the economic situation of the interviewee, which is only slightly significant. At first sight, it would seem that, when a person is in a bad economic situation, the probability that he/she prefers that people who cannot care for themselves turn to public services rather than to family would increase. However, the model shows that, when we introduce the variable of family structure and relationships among its members, the economic variable loses its significance.

In the fourth block of the model we can observe that the degree of confidence in social services is not significant and explains nothing. This indicates that prioritizing social services rather than family care does not depend on having confidence in the quality of social services. As Bazo and Ancizu (2004) argue, Spaniards attach very little value to social services, know even less about them, and have little information about how they work.

The fifth and sixth blocks' variables are related to the structure and internal dynamics of the family. The results show that Spaniards' preferences for family dependants' caring options -social services or family care-, depend on such family features as human capital (number of potential caregivers), degree of family cohesion, and emotional wellbeing with family members. First, human capital, understood as the number of potential caregivers that a person think he can count on if necessary, is important. For someone with a limited number of people who could take care of him/her, the odds ratio of considering that it is better to rely on social services for the care of family dependants rather than on family care doubles that of someone with a great human capital. Second, the 
degree of family cohesion is also an important and significant variable. In families where there is frequent contact between its members, where they visit each other frequently and where they share feasts regularly, the likelihood that you prefer that social services primarily take care of elderly dependent family members is lower than in less cohesive families. Finally, the degree of satisfaction with the family exerts a determinant and statistically significant bearing on the probability of preferring social services in front of family care as a caring option for the family dependants. The probability of preferring social services is $30 \%$ higher if you have a medium satisfaction with your family and $220 \%$ higher if the degree of satisfaction with your family is low. Taking care of your parents when they need it is no longer an unavoidable obligation in Spain. Our data indicates that it depends on the quality of the relationship between parents and children.

This last finding is empirically relevant because it questions the sustainability of the Spanish model as it has been defined so far by the existing literature. Moreover, this finding is consistent with recent conclusions of the OASIS Project comparing five countries (Norway, Germany, United Kingdom, Israel and Spain). "Family exchanges may be becoming less duty-driven and more open to individual variation, and personal affection and attachment may be increasingly important for family cohesion and inter-generational ties. Normative obligations live on, but may increasingly be modified by affection and choice, so that family relationships are transforming" (Lowenstein and Daatland 2006: 219).

Just as a way to illustrate this finding we use data from a few qualitative in-depth interviews from the COGEASDO study. ${ }^{11}$ From the interviews to people older than 65 we note that the feeling of obligation to take care of their parents is very strong. Most people interviewed in this generation say that they take care of their parents at home because they loved them and they wanted to make sure they received the best care. But they also pointed out a sense of obligation to those who had taken care of them, educated, and emotionally and financially helped them throughout life. Nevertheless, some people interviewed from this generation do not share these feelings of affection and obligation to their parents due to problems of poor relationship between them or even because their parents were not caregivers. Even so they feel forced to take care of their parents due to the strength of social norms, as in the case of the following testimony:

"The relationship with my parents was cold because we stood apart during the days of childhood. [...] I was born during the war. During the post-war period my family had problems. My mother sent me to live with my grandmother. I lived with my grandparents until they died, and I knew my parents when I was grown up. [...] However, I took care of my mother. I could not take care of my father because he was self-sufficient until he died. [...] We always took care of

\footnotetext{
${ }^{11}$ The Generational Contract Modification and Home Care Policy Project (COGEASDO) was founded under the National Plan of R+D of the Spanish Ministry of Science and Technology. Spaniards from two different generations were interviewed in order to see whether there have been changes in the generational contract within the family. The first generational group interviewed consists on people over 65 years. Women from this generation have been educated as homemakers and have cared for their parents. The second group interviewed consists on people from 30 to 50 years old. Unlike their parents, usually the two partners are active in the labor market. We want to find out whether they would be willing to care for their parents if necessary. Both groups were stratified by gender and social class (depending on household income and profession).
} 
my mother. I think that it was a kind of duty. If I had had a bad relationship with her, we would have taken care of her anyway." 12

As shown in this excerpt, individual factors such as the case of intergenerational reciprocity were not a necessary condition to take care of parents. The explanation is due rather to the existence of strong normative social constructions. This is even clearer in the case of people who have to take care of people for whom they have no affection or debt (for example, in-laws or widowed aunts and uncles) or even for people with whom you have a bad relationship. In these cases, what counts is the duty. A duty that is linked to social norms, as it is shown in this passage:

"We were poor but my husband's mother was from a rich family. She wanted his son to marry a girl with more money than me. She was widowed very young and because of that she leaned heavily on her son. She never accepted me. [...] We had an extremely bad relationship. She even hit me and wanted to kill me, but it was me who took care of her. I have never been able to forgive everything she did. I took care of her because it was my duty, because it was my mother-in-law, if it had not been the case, I hadn't done so. [...] My husband always supported me. Otherwise, I would have gone. It upset me that my children grew up in this environment and that they hated her. My life was very hard until she died." 13

Some of the interviews made to people from the generation of 30 to 50 years old showed that the social norm of taking care of an elderly dependant under any circumstance is not as strong. Increasingly, the decision of taking care of elderly dependent family members personally depends on the quality of the relationship you have had with them. The arguments of this 39 years old woman with divorced parents provide a good example:

"I feel responsible for my mother, but not so much for my father. This is due to a poor relationship with him, nothing else. It's always been like this. If the relationship had been more or less good with both, I would have felt responsible for both. The problem is that it was bad with one of them." 14

In other interviews, it is shown that it is difficult to break a social norm as strong as the obligation to take care personally of your parents. In many people interviewed we found a dichotomy between rhetoric and practice. Interviewees create an acceptance speech and even protection of the standard of being a caregiver. But for them the meaning of "care" is not the same as for their parents and grandparents. When some interviewed people talk about the obligation of taking care of their parents, normally, they are not referring to take care of them by themselves. They mean that they will undertake to provide that care. This excerpt puts it clearly:

"We take care of them because it is our responsibility. I feel very responsible for my parents. We have always tried that they were well served. We have not

\footnotetext{
${ }^{12} 68$ years old man. He is an engineer and worked in textile companies and automotive. Interviewed on May 19, 2006 at her home in Barcelona.

${ }^{13} 69$ years old woman. He has worked all his life in a delicatessen. Interviewed on March 18, 2006 at her home in Puigcerdá (Lerida).

${ }^{14} 39$ years old woman. Married with two children. She studied psychology and is a college professor. Her parents are alive, in good health and self-sufficient. They get divorced many years ago. Interview on Saturday March 25, 2006 at $5 \mathrm{pm}$ at her home in Terrassa (Barcelona).
} 
done the work personally, like changing diapers, because we couldn't. If you have a job and children you cannot make such things. The solution is to put a person to look after them, and what we do is to control that person. We are always aware of how things go and if they are well served." 15

As OASIS Project concluded, normative beliefs are sufficiently flexible to adapt to new social realities such as gender equality and increased female participation in paidwork (Lowenstein and Daatland 2006). There are different ways in which filial norms are translated into emotional and instrumental support and help. Having sufficient financial resources takes pressure off from the social norm, and therefore children are able to choose how far they will be involved eventually as caregivers of their parents. They can weigh up the pros and cons of their decision and, if they take care of their dependants, it will be more satisfying because it has been freely chosen. By contrast, most of the families that do not have sufficient financial resources to hire private care for their elderly dependants may feel they have no choice other than assuming such responsibility directly. As Sarasa and Billingsley (2008) concluded, in countries where home care is provided mainly by the market, as in Spain, is where we can find more social class inequalities. In fact, the poorer children cannot afford the services and they have to bear the care burdens more than the richest ones.

\section{Conclusion}

Caring for elder dependent parents is no longer perceived by the Spaniards as an unavoidable moral duty. Instead, the traditional preferences for family care over state care that have characterized the Spanish care model are strongly influenced by the existence of good personal relations among family members. Our analysis of recent data on Spaniards' preferences concerning the care of their family dependents shows that the degree of satisfaction with the family exerts a determinant and statistically significant bearing on the probability of preferring either state or family care. The higher is the satisfaction with family relations, the higher is the probability of preferring family care; the lower such satisfaction, the higher the probability of preferring state care. Also, in families where there is not frequent contact between its members the likelihood of preferring social services is higher than in more cohesive families. Our findings could confirm our first hypothesis that new familiar realities, such as gender equity and increased female participation in paid work, make people's preferences about family care be less dutydriven and more dependent on personal affection and attachment.

Our findings partially confirm our second hypothesis. The data indicate that family network influence Spaniards' preferences concerning dependence care. People with poor family networks or little cohesive families have a higher probability of preferring to rely on state social services for the care of their dependants. The lower the number of potential caregivers, the more likely it is that they prefer social services. However, the economic

\footnotetext{
1543 years old woman with three children. She is an entrepreneur, running a family business. She has people hired during the day. Somebody takes care of her mother and before somebody took care of her aunt. Interviewed on July 11, 2006 at her home in Sant Cugat del Vallès (Barcelona).
} 
situation does not have an influence on a preference for a particular way of caring for dependants. Our findings show that a bad economic situation does not necessarily lead to somebody preferring social assistance care for elderly dependants rather than family care.

Other interesting results of our study show that people in the age group between 51 and 65 show a higher probability to prefer state care for elder dependent relatives. This is the group that fits the higher frequency of caregiving and confronts more often the incompatibility between caregiving to aged parents and paid employment. Our data also indicate that preferences for social services over family care do not depend on either trust on or knowledge of such social services.

We can conclude that the profound economic and social changes in Spanish families may have changed the dynamics of family solidarity. Our study about preferences indicates that Spaniards no longer feel caring personally for their dependent parents as an unavoidable moral duty. Although it is difficult to break a social norm as strong as the obligation to take care personally of one's parents, normative beliefs are sufficiently flexible to adapt to new social realities such as gender equality and increased female participation in paid-work. In Spain, the generation contract by which children should care for their dependent parents is still alive, but nowadays such obligation is defined and understood in a more flexible way -that is, there are different ways in which filial norms are translated into emotional and instrumental support and help. In-depth interviews excerpts included in this article give us some clues for further interesting hypothesis for further research -for example, these interviews point out that, at least in some cases, sufficient financial resources may take pressure off the social norm of caring personally for them. However, a large majority of Spanish families don't have enough money to afford private services and have difficulties assuming the caring role given to family by the Spanish welfare state. This is even more relevant in a country where public resources devoted to elder care are extremely scarce.

Finally, some limitations of the data should be considered. First, the data we use in our statistical model are exclusively cross-sectional. A longitudinal design would have provided a more dynamic picture, but the necessary data to do so are not available. Second, the data we use give information about Spaniards' preferences in relation to who should take care of elder dependents -either family or the state-. This is why we do not take for granted that preferences and dispositions are predicting future behaviours and practices. However, such data do allow us to analyse the strength of expressed filial obligations (normative solidarity). Third, the interview excerpts used in this article do not have analytical purposes, but are only aimed at illustrating the Spanish reality and better contextualize the statistical findings.

\section{References}

Bazo, M. T. Ancizu I. (2004) "El papel de la familia y los servicios en el mantenimiento de la autonomía de las personas mayores: una perspectiva internacional comparada" Revista Española de Investigaciones Sociológicas, 105: 45-73. 
Beck, U (1997 [1986]) La sociedad del riesgo (Barcelona: Paidós).

Brullet, C. and Torrabadella, L. (2004) "La infáncia en las dinámicas de transformación familiar”, pp. 37-61 in Gómez-Granell, C. et al. Infancia y familias: realidades y tendencias (Barcelona: Ariel).

CIS (2010) Estudio CIS nº 2.844: Barómetro de se septiembre de 2010 (Madrid: CIS).

CIS (2004) Estudio CIS no 2.581: Barómetro de noviembre de 2004 (Madrid: CIS).

Daatland, S. O. and Lowenstein, A. (2005) "Intergenerational solidarity and the familywelfare state balance" European Journal of Ageing, 2: 174-182.

EUROSTAT (2010) Employment in Europe, 2010 (Luxembourg, European Commission).

EUROSTAT (2010) Healthcare statistics

(http:epp.eurostat.ec.europa.eu/statistics_explained/index.php/Healthcare_statistics).

Flaqué, L1., Almeda, E. and Navarro, L. (2006) Monoparentalitat i infància (Barcelona, Fundació la Caixa).

Gouldner, A. W. (1960) "The norm of reciprocity" American Sociological Review, 25 : 161-178.

INE (2012) Indicadores Demográficos básicos. Indicadores de crecimiento y estructura de la población. Series 1975-2010 (Madrid, INE)

INE (2008) Encuesta de discapacidad, autonomía personal y situaciones de dependencia: EDAD (Madrid, INE).

Ingebretsen, R. and Eriksen, J. (2004) EUROFAMCARE: National Background Report for Norway (http:www.uke.uni-hamburg.de/eurofamcare/).

Iglesias de Usel, J. Marí-Klose, P. Marí-Klose M. and González Blasco, P. (2009) Matrimonios y parejas jóvenes. España 2009 (Madrid: Fundación SM).

Knijn,T. (2004) "Family solidarity and social solidarity: substitutes or complements?", pp. 18-33 in T. Knijn, T. Komter, A. (eds.): Solidarity between the sexes and the generations (Cheltenham/Northampton: Edward Elgar).

Lowenstein, A. and Daatland, S.O. (2006) "Filial norms and family support in a comparative cross-national context: evidence from the OASIS study" Ageing \& Society, 26: 203-223.

Marí-Klose, P. and Marí-Klose, M. (2006) Edad del Cambio: Jóvenes en los circuitos de solidaridad intergeneracional (Madrid: CIS).

Marshall V., et al. (1987) “Older parents' expectations for filial support” Social Justice Research, 1 (4): 405-424.

Meil, G (2006) Pares i fills a l'España actual (Barcelona, Fundació la Caixa).

Ministerio de trabajo y Asuntos Sociales (2005) El Libro Blanco de la Dependencia, Madrid: Ministerio de trabajo y Asuntos Sociales).

Moreno, F. J. and Bruquetas, M. (2011) Inmigración y Estado de bienestar en España (Barcelona: Fundació la Caixa). 
Tobío, et al. (2010) El cuidado de las personas: Un reto para el siglo XXI (Barcelona: Fundació la Caixa).

Rainwater, L. Rein, M. and Schwarz, J. (1986) Income Packaging in the Welfare State: A comparative Study of Family Income (Oxford: Oxford University Press).

Sarasa S. (2008), "Do Welfare Benefits Affect Women's Choices of Adult Care Giving?" European Sociological Review 24 (1): 37-51.

Sarasa, S. and Billingsley, S. (2008) "Personal and household care giving from adult children to parents and social stratification" pp. 123-146 en C. Saraceno (ed.) Families, Aging and Social Policy Edward \& Elgar.

Sarasa, S. (2007) "La atención a las personas adultas dependientes en España: desigualdades territoriales y estratificación social" pp 445-470 en Navarro,V (ed.) La situación social de España II. (Madrid: Biblioteca Nueva).

Sarasa, S. and Mestres, J. (2007) "Women's Employment and the Adult Care Burden" pp. 185-221 in G. Esping-Andersen (ed.) Family Formation and Family Dilemmas in Contemporary Europe FBBVA.

Van de Kaa, D. J. (1987) “Europe's second demographic transition”, Population Bulletin, 41: $1-57$. 